\title{
Feeling the Nation through Exploring the City: Urban Pedagogy and Children's Lived Experiences in Postwar Helsinki
}

\author{
Antti Malinen and Tanja Vabtikari
}

\section{INTRODUCTION}

In addition to adults, children, even very young children, negotiate different ideas, practices and emotions with respect to the national community. ${ }^{1}$ In their daily lives, children encounter various patterns of emotional formation: they learn from different and sometimes conflicting agents what and how they should be feeling, and, in contrast, what they should not express in a given situation. ${ }^{2}$ School, especially through its curricula work,

${ }^{1}$ Zsuzsa Millei, "Pedagogy of nation: A concept and method to research nationalism in young children's institutional lives," Childhood 26:1 (2019), 83-97.

${ }^{2}$ Karen Vallgårda, Kristine Alexander \& Stephanie Olsen, "Emotions and the Global Politics of Childhood," in Childhood, Youth and Emotions in Modern History: National, Colonial and Global Perspectives, ed. by Stephanie Olsen (Basingstoke, Hampshire: Palgrave Macmillan 2015), 12-34, here 21.

A. Malinen $(\bowtie) \bullet T$. Vahtikari

Tampere University, Tampere, Finland

e-mail: antti.malinen@tuni.fi; tanja.vahtikari@tuni.fi

(C) The Author(s) 2021

V. Kivimäki et al. (eds.), Lived Nation as the History of Experiences

and Emotions in Finland, 1800-2000, Palgrave Studies in the

History of Experience, https://doi.org/10.1007/978-3-030-69882-9_13 
is one of the key institutional settings for the state to advance its national(ist) agendas and to place emotional expectations on children. It is also a site for "unseen, unheard, unnoticed" everyday nationalism: the mundane (re)production of national frameworks through situated activities. ${ }^{3}$ At schools, everyday nationalism is present, for instance, in language use, embodied practices, priorities given to certain values, daily schedules, and in children's encounters with spatial and material realities. ${ }^{4}$

In Finland, the emotional education of children remained entangled with the category of nation in the post-World War II period, even though the nationalist sentiments in society had cooled down from the hot period of the interwar years. As in many other European societies, children were seen to bring hope for future reconstruction after the long and devastating war. ${ }^{5}$ At the same time, it needs to be kept in mind that most children in the immediate postwar era had a first-hand experience of wartime. As historians of postwar childhood have asserted, the period saw highlighted interest in children's emotions and in emotional reconstruction (that complemented material reconstruction) as part of social policy. ${ }^{6}$

The setting for our chapter is postwar Helsinki, and our point of departure is the classroom. We explore the emotional-national education of children by adults through the means of pedagogy, particularly the manner in which children were taught various (emotional) competences and skills, which were understood as a means to advance their becoming attached to the local and national community. This said, our aim is not to pursue only a top-down view but to bring into the analysis the complexity of children's experiencing of the nation. In this vein, early childhood educationalist Zsuzsa Millei has introduced the "pedagogy of nation"

${ }^{3}$ Jon E. Fox, "The edges of the nation: a research agenda for uncovering the taken-forgranted foundations of everyday nationhood," Nations and Nationalism 23:1 (2017), 26-47, here 27. See also Rhys Jones \& Peter Merriman, "Hot, banal and everyday nationalism: Bilingual road signs in Wales," Political Geography 28:3 (2009), 164-73.

${ }^{4}$ For institutional care of young children, see Millei (2019), 84.

${ }^{5}$ Machteld Venken \& Maren Röger, "Growing up in the shadow of the Second World War: European perspectives," European Review of History-Revue europeénne d'histoire 22:2 (2015), 199-220, here 199.

${ }^{6}$ Roy Kozlovsky, "Architecture, Emotions and the History of the Childhood," in Childhood, Youth and Emotions in Modern History: National, Colonial and Global Perspectives, ed. by Stephanie Olsen (Basingstoke, Hampshire: Palgrave Macmillan 2015), 100-1; see also Harry Hendrick, "Children's Emotional Well-being and Mental Health in Early Post-Second World War Britain: The Case of Unrestricted Hospital Visiting," Cultures of Child Health in Britain and the Netherlands in the Twentieth Century, ed. by Marijke Gijswijt-Hofstra \& Hilary Marland (Amsterdam: Rodopi, 2003), 213-42, here 214. 
concept, which, by complementing the more often used concept of "national pedagogy" that focuses on intentional pedagogy, calls attention to the "complex process through which the nation is (re)produced in [children's] everyday life." In this chapter we argue that children in the postwar era negotiated their emotions and their emotional belonging to the nation in manifold and often subtle responses to the national stocks of experience that were offered to them through educative processes and in various material and spatial everyday bodily encounters. Our chapter thus sets out to examine how educators, children, and urban space coproduced the nation in relational everyday (school) practices.

Children's emotional experiences, as with wider emotional styles in society at a given time, are inherently spatial and material. Emotions interact with the spaces construing them and those emotions are in turn shaped by the kinds of spaces in which they are performed. Different spaces thus become linked to different emotions. ${ }^{8}$ As pointed out by historians Karen Vallgårda, Kristine Alexander and Stephanie Olsen, children have "had to learn to navigate diverse emotional spaces and collectives," ranging from home and school to playground, and, in our case, to the wider urban environment where very different emotional norms were set by parents, teachers and peers. ${ }^{9}$ It is also possible to view children's encounters with their environment and the material world as a form of "non-human teacher" 10 in the processes of everyday nationalism and emotional formation. Following cultural geographers Rhys Jones and Peter Merriman, we see national forces and affects as something that circulated between bodies inhabiting and moving through particular spaces. ${ }^{11}$

During the first half of the twentieth century, kotiseutuoppi, "knowledge of the home" (in German Heimatkunde, in Swedish hembygdslära) was high on the agenda of Finnish elementary education. Kotiseutuoppi was a pedagogy that contended that knowledge of the local community and the child's own experience should occupy an important place in all

${ }^{7}$ Millei (2019), 84-5.

${ }^{8}$ Benno Gammerl, "Emotional styles - concepts and challenges," Rethinking History, 16:2 (2012), 161-75; Margrit Pernau, "Space and Emotion: Building to Feel," History Compass 12:7 (2014), 541-9, here 542 .

${ }^{9}$ Vallgårda, Alexander \& Olsen (2015), 22.

${ }^{10}$ Millei (2019), 85.

${ }^{11}$ Peter Merriman \& Rhys Jones, "Nations, materialities and affects," Progress in Human Geography, 41:5 (2017), 600-17, here 602. 
education. ${ }^{12}$ Kotisentuoppi was believed to offer a way to develop children's attachments to their local everyday environments, urban and rural, and, more broadly, to the nation. A significant feature of kotisentuoppi pedagogy, or environmental education (both terms were used), was the idea that children should reflect their experiences of locality, at-homeness, by writing, drawing and exploring their environment. In this chapter, we will focus on the latter-two-mentioned intertwined practices, drawing and exploring the environment, both of which we understand as emotional practices. As Monique Scheer asserts, "practices not only generate emotions but [...] emotions themselves can be viewed as a practical engagement with the world." 13

In this chapter, we use two sets of contemporary sources from the immediate postwar period: educators' writings published in professional publications as part of the national curriculum work, and young children's drawings from one Helsinki school, the Käpylä primary school. The drawings are archived in the Aalto University's History of Art Education Archives (HAE). The collection contains around 30,000 works, ${ }^{14}$ which makes it a rare resource even internationally. ${ }^{15}$ A large part of the material consists of works entered in competitions that were organized yearly by the National Board of General Education. In addition, individual schools such as Käpylä elementary school sometimes decided to donate their archives to the HAE archive. Typically, school archives were created by an individual teacher who had collected students' works over the years and wanted to preserve the works as historical examples of contemporary art

\footnotetext{
${ }^{12}$ Heidi Hilli-Tammilehto \& Sirpa Tani, "Kotiseutuopetuksesta ympäristö- ja luonnontietoon: lähiympäristön huomioon ottaminen suomalaisessa kouluopetuksessa," Terra 111:2 (1999), 69-76.

${ }^{13}$ Monique Scheer, "Are Emotions a Kind of Practice (and Is That What Makes Them Have a History)? A Bourdieuian Approach to Understanding Emotion," History and Theory 51:2 (2012), 193-220, here 193.

${ }^{14}$ Pirkko Pohjakallio, "A Hundred Years of Art Education in Finland - An Exhibition," in Power of Images, ed. by Liisa Piironen (Helsinki: InSEA Finland \& The Association of Art Teachers in Finland, 1992), 18, 86-93.

${ }^{15}$ For an international reflection, see, for example, Carolyn Kay "Children's Drawings as Historical Sources for the Study of Education in World War One," in Transformationen von Schule, Unterricht und Profession: Erträge praxistheoretischer Forschung, ed. by Kathrin Berdelmann, Bettina Fritzsche, Kerstin Rabenstein \& Joachim Scholz (Wiesbaden: Springer, 2019), 185-212.
} 
education. ${ }^{16}$ The Käpylä school archive was collected by the elementary school teacher Dagmar Kemilä (1891-1961). Focusing on one school and one teacher allows for the contextualization of our case into a specific urban place, and permits an in-depth look into the practice of drawing (preceded by urban excursions), from the co-creative perspective that existed between the teacher and the children.

Out of a total of 206 Käpylä school pieces of work, we have collected all drawings and paintings that depict spaces (public/private, outside/inside) and environment, focusing on urban topics but also including images depicting more rural/forest-like environments (which still very widely existed in Finnish cities in the immediate postwar years). Our sample includes around 150 drawings and paintings made by small children, girls and boys, aged from six to eight. ${ }^{17}$ When analyzing children's art, agebased variations are important to keep in mind: whereas older children tend to focus on realism, younger children take more freedom in their representations. ${ }^{18}$ Images in which realism was not necessarily a primary concern also form a prominent group in our sample data. Another category to think about is gender, something that shaped notions of national belonging, even when girls and boys took part in joint excursions and drawing classes, and thus shared common experiences. While taking due notice of this, we will, nevertheless, not explore gender as a main analytical category, because, as earlier research has convincingly shown, gender differences are a less significant variable with regard to young children's drawings. ${ }^{19}$

The meanings of any images, including drawings, are made at three main sites: the site of the production of the image, the site of the image itself and the site of the audience. ${ }^{20}$ The main focus of this chapter is on

\footnotetext{
${ }^{16}$ Juuso Tervo, "Mistä kuva todistaa? Arkistoidut oppilastyöt, historiankirjoitus ja kuvataidekasvatuksen historian toisinkirjoittaminen," in Jälkikuvia, kuvan jälkiä: Lasten ja nuorten taiteen tallentaminen ja tutkiminen, ed. by Päivi Venäläinen, Jemina Lindholm, Seija Kairavuori, Tiina Pusa \& Susanne Ylönen (Helsinki: Nuorisotutkimusseura, 2019), 169-90.

${ }^{17}$ In the archive, works are divided into eight series. Aalto University Learning Centre (Helsinki), History of Art Education Archive, Aa.120:01-Aa.12:08.

${ }^{18}$ Manon Pignot, "Drawing the Great War: Children's Representations of War and Violence in France, Russia and Germany," in War and Childhood in the Era of the Two World Wars, ed. by Mischa Honek \& James Marten (Cambridge: Cambridge University Press 2019), 170-88, here 173.

${ }^{19}$ Pignot (2019), 173.

${ }^{20}$ Gillian Rose, Visual Methodologies: An Introduction to Researching with Visual Materials, 3rd ed. (Thousand Oaks, Calif: Sage Publications, 2012).
} 
the site of the production, which we understand to be a highly complex site, extending beyond any physical site, including the classroom, the school, the urban excursions preceding the drawing, the pedagogical framework, the teacher's engagement and, most importantly, the drawing child herself/himself and the practice of drawing. In our analysis, it is also important to take into consideration the regional differences in Finland. In the capital city of Helsinki, new ideas and curriculum objectives were adopted more quickly compared to smaller cities and rural areas. Some teachers in Helsinki, such as Dagmar Kemilä, innovated and pioneered new techniques, and influenced teacher education nationwide.

Despite our focus on drawing as a practice, we do not intend to overlook in our analysis the other two sites mentioned above: the site of the image and that of the audience. Drawings and paintings constitute a history of experience source similar to other firsthand, personal accounts by historical actors; they do not offer any direct route to an "authentic" self. ${ }^{21}$ A form of self-expression that lies behind the drawings "is hybrid, complex and polychromatic." 22 Cultural historian Mary Tomsic has suggested that it might be valuable to think about children's drawings as both "aesthetic and social objects," as meanings are created in the particular context where the drawings are used. Similarly, it is important to disentangle the histories and frames of children's drawings, the purposes that the drawings might have served and their real or imagined audiences. Social context affects how experiences can be organized and represented. ${ }^{23}$

\section{Postwar Helsinki Schools in Context}

In Helsinki, as in many other European cities, war was followed by rapid urban growth. At the beginning of the twentieth century, Helsinki had already become regarded as a city of "newcomers," due to a high level of migration from rural areas and smaller cities. In the aftermath of World War II, the population growth was fueled by a high birthrate, work-related

${ }^{21}$ Mary Tomsic, "Children's Art: Histories and Cultural Meanings of Creative Expression by Displaced Children," in Children's Voicesfrom the Past: New Historical and Interdisciplinary Perspectives, ed. by Kristine Moruzi, Nell Musgrove \& Carla Pascoe Leahy (Cham: Springer Nature Switzerland, 2019), 138.

${ }^{22}$ Manon Pignot, "The crayon war: how children drew the Great War," in War and Art: A Visual History of Modern Conflict, ed. by Joanna Bourke (London: Reaktion Books, 2017), 311-12.

${ }^{23}$ Tomsic (2019), 138-41; Pignot (2017); Margaret Higonnet, "Child Witnesses: The Cases of World War I and Darfur," PMLA 121:4 (2006), 1565-76. 
migration and resettlement of evacuees from areas that Finland had ceded to the Soviet Union under the terms of the armistice agreement-most importantly Finnish Karelia, located on the border of Finland and Russia. ${ }^{24}$ By early 1945, some 30,000 displaced people, mainly from Finnish Karelia, were living in Helsinki. ${ }^{25}$

For the newcomers, arrival and settlement in Helsinki brought challenges, as most places were unfamiliar and orientation in the city was in itself difficult. On an emotional level, migration to Helsinki was especially difficult for Karelian evacuees, as well as for the so-called war children who, during and immediately after World War II, had been evacuated abroad from Finland, mainly to Sweden and Denmark (around 11,000 were sent from the Helsinki area in 1941-1946). ${ }^{26}$ It can be argued that children belonging to these two groups experienced a sense of liminality after their return. They not only experienced a loss of home "there" (in Karelia or in Sweden), but also struggled to find their place and a sense of belonging in the present-day Helsinki. Many of the displaced families were forced to continue living in conditions similar to those caused by wartime evacuations, such as those to be found in emergency shelters and cheap hostels. Overall, due to a severe housing shortage, apartments in Helsinki were overcrowded, and people were sometimes desperately seeking adequate permanent dwellings.

The modernist urban renewal in Helsinki was actualized on a broader scale only from the mid-1950s onward. However, immediately after the war new buildings already started to appear in the city. The urban space was in transition both socially and materially. One such area was Käpylä, originally built in the 1920s, and one of the fastest growing neighborhoods in Helsinki in the postwar period. Between 1939 and 1954 the area's population tripled to 12,300 . As a result, Käpylä was one of the districts in Helsinki that had the most children, a fact that had a significant influence on the functioning of the Käpylä elementary school. In the

${ }^{24}$ Tanja Vahtikari, “'Washing Away the Dirt of the War Years': History, Politics and the Reconstruction of Urban Communities in Post-World War II Helsinki," in (Re)Constructing Communities in Europe, 1918-1968: Senses of Belonging Below, Beyond and Within the NationState, ed. by Stefan Couperus \& Harm Kaal (New York: Routledge, 2017), 65-84.

${ }^{25}$ The overall number of evacuees from ceded areas was 430,000. Antti Malinen, Perheet abtaalla: Asuntopula ja siihen sopeutuminen toisen maailmansodan jälkeisessä Helsingissä 1944-1948 (Helsinki: Väestöliitto, 2014), 153-4.

${ }^{26}$ Heikki Salminen, Lappu kaulassa yli Pohjanlabden. Suomalaisten sotalasten historia (Turku: Siirtolaisinstituutti, 2007), 200. 
immediate postwar years, over 1200 children received instruction there, often in as many as three daily shifts. ${ }^{27}$

Wartime experiences fostered the notion of society as a functional whole that could be steered and rationalized by means of scientific knowledge. The postwar Finnish society faced a major challenge in demobilizing and reintegrating over half a million former soldiers, resettling around 430,000 evacuees from the ceded areas, and stabilizing the society. Overcoming social conflicts and supporting integration and social cohesion became major policy issues, issues that were also reflected in the objectives of the school curriculum. ${ }^{28}$

In the interwar years, the primary school curriculum had mainly been based on religious, moral and patriotic values. ${ }^{29}$ During wartime, primary schools had taken part in the promotion of values, such as self-sacrifice, honor and heroism, which served the purposes of a belligerent nation and its war propaganda. In the postwar period, moral and patriotic questions of love for the nation remained important, along with an emphasis on social cohesion, but these features were reframed in reference to new models of state and citizenship. In the post-1945 world, Finland adopted a policy of neutrality, according to which the priority was to develop working and peaceful relations with the Soviet Union, and to maintain a balanced relationship between East and West. The conditions of the September 1944 Moscow Armistice required Finland to ban organizations conceived to be fascist and paramilitary and to rehabilitate the Communist Party. A Soviet-led Allied Control Commission was established in Helsinki to make sure that Finland would comply with the obligations of the Armistice. According to the new foreign policy, previous right-wing rhetoric and chauvinism were (self-)censored from the public sphere, and there were also some (mostly unsuccessful) attempts by the Finnish Far

\footnotetext{
${ }^{27}$ Helsingin kaupungin tilasto (HKT) VI, Opetuslaitokset 1945/1946-1946/1947, 40; HKT, Opetuslaitokset 1947/1948-1948/1949, 43.

${ }^{28}$ Pauli Kettunen, "Wars, Nation, and the Welfare State in Finland," in Warfare and Welfare: Military Conflict and Welfare State Development in Western Countries, ed. by Herbert Obinger, Klaus Petersen \& Peter Starke (Oxford: Oxford University Press, 2018), 260-89, here 284 .

${ }^{29}$ Hannu Simola, "From exclusion to self-selection: examination of behaviour in Finnish primary and comprehensive schooling from the 1860s to the 1990s," History of Education 31:3 (2002), 207-10; Saara Tuomaala, "Kinoksia ja kivikkokankaita: Koulutie suomalaisen modernisaation kokemuksena ja metaforana," in Modernisaatio ja kansan kokemus Suomessa 1860-1960, ed. by Hilkka Helsti, Laura Stark \& Saara Tuomaala (Helsinki: Finnish Literature Society, 2005), 241-76.
} 
Left to purge civil servants and teachers considered to be incompetent and politically biased. ${ }^{30}$ The postwar period also brought less politically motivated changes to the educational debate, drawing from viewpoints and concepts that reflected individual experiences of war and its horrors. Earlier ideals of obedience and loyalty, and even of patriotism, began to be questioned and were superseded by the ambition to foster democratic values and more peace-loving citizens. Similar ideas were also promoted in postwar Sweden. ${ }^{31}$

Now the main task of a school was to train competent and supportive future citizens suited for democratic life, ${ }^{32}$ as pointed out by the Elementary School Committee of 1946:

\begin{abstract}
The demands of a democratic society require that future citizens be taught to become independent, free personalities, and that their individual traits are valued. Democratic life is possible only when these individuals are educated in mutual collaboration. Future citizens must be righteous, unselfish, tolerant and self-restrained, since these qualities advance social organization based on mutual solidarity. ${ }^{33}$
\end{abstract}

According to Matti Koskenniemi, who worked as a secretary of the Committee for the Elementary School Curriculum, the "new school" should take advantage of pupils' activity, as this would promote their social maturation. ${ }^{34}$ This view was echoed in the new 1952 Curriculum, in which school was described as a "miniature society" and an arena for interaction

${ }^{30}$ Ville Kivimäki, "Between Defeat and Victory: Finnish Memory Culture of the Second World War," Scandinavian Journal of History 37:4 (2012), 482-504, here 487; Jukka Rantala, Sopimaton lasten kasvattajaksi! Opettajiin kohdistuneet poliittiset pubdistuspyrkimykset Suomessa 1944-1948 (Helsinki: Finnish Literature Society, 1997).

${ }^{31}$ For Sweden, see Johan Östling, Sweden after Nazism: Politics and Culture in the Wake of the Second World War (New York: Berghahn, 2016), 182.

${ }^{32}$ Simola (2002), 109; Leevi Launonen, Eettinen kasvatusajattelu suomalaisen koulun pedagogisissa teksteissä 1860-luvulta 1990-luvulle (Jyväskylä, Jyväskylän yliopisto, 2000), 205; Antti Saari, "Technique of Freedom: Representing the School Class as a Social Order," in $A$ Political Sociology of Educational Knowledge: Studies of Exclusions and Difference, ed. by Thomas A. Popkewitz, Jennifer Diaz \& Christopher Kirchgasler (New York: Routledge, 2017), 211-28, here 217. For the love of the nation in the context of the postwar kotisentuopppi-education, see Aukusti Salo, Kolmiluokkaisen alakansakoulun työn järjestäminen ja opetussuunnitelmat (Helsinki: Otava, 1948), 26.

${ }^{33}$ Committee for the Elementary School Curriculum Report 1946:2, 4.

${ }^{34}$ Matti Koskenniemi, Sosiaalinen kasvatus koulussa (Helsinki: Otava, 1952), 12-13. 
between students and teachers. ${ }^{35}$ Life in school was to be shaped into an educative training ground emphasizing civic rights and duties. For these purposes, kotisentuoppi pedagogy set out to develop children's physical and psychological capacities, as well as their social skills. The idea was to train children to express themselves in a variety of ways: to begin with by exercising the whole body, especially the hand, and gradually moving on to training children's abstract thinking. Different school aspects, such as crafts, drawing, reading and writing were seen as ways to accomplish this, since they were believed to satisfy children's basic need for activity. ${ }^{36}$ When considered from the point of view of producing national belonging, the focus of attention was first placed on tangible features of the nation. ${ }^{37} \mathrm{In}$ the following two sections, we will focus on two activities, exploring the local environment and drawing, which, in the pedagogy of the time, were considered mutually supportive. In addition, we have chosen a few drawings, representative of our material, for a closer analysis. By examining the two practices and the drawings together, and in relation to postwar educational objectives aiming to teach children emotional competences, we will discuss the nation as educated, learned and lived space for/of children.

\section{Exploring The City}

In kotiseutuoppi pedagogy, shaping the child emotionally became closely linked to national-patriotic education, which aimed to evoke love for the local community and the local environment, and, via these encounters, for the nation. The objective was not only to teach children how to make observations concerning the surrounding world and to gather information based on these observations, but to "awaken the child's intellectual, volitional and emotional abilities in their entirety." ${ }^{38}$ Key to these "lived, emotional and recreational stimuli" was seen to be the child's "own experience." 39

The kotisentuoppi education has been associated with promoting mainly rural and traditional values. Nevertheless, it was also considered important in the faster-changing postwar urban contexts. While the rural version

${ }^{35}$ Committee for the Elementary School Curriculum Report 1952:3, 28.

${ }^{36}$ Matti Koskenniemi, Kansakoulun opetusoppi (Helsinki: Otava, 1944), 298-9.

${ }^{37}$ See also Josephine Hoegaerts, "Learning to love: Embodied practices of patriotism in the Belgian nineteenth century classroom (and beyond)," in Emotions and everyday nationalism in modern European History, ed. by Andreas Tynen, Maarten van Ginderachter \& Xosé M Núňez Seixas (London: Routledge, 2020), 79.

${ }^{38}$ Aukusti Salo, Alakansakoulun opetusoppi II: Kotiseutuopetus(Helsinki: Otava, 1934), 18.

${ }^{39}$ Salo (1934), 15. 
found purpose through referring to threats of urbanization, in postwar Helsinki, the reasoning was quite the opposite: kotisentuoppi education was seen as a way to integrate newcomers into the urban community. There were concerns as to whether a genuine love for home could exist within the context of the expanding metropolis of Helsinki. ${ }^{40}$ For these purposes, as early as the late 1930s, the Helsinki Society had published a series of schoolbooks especially designed to teach history and geography in Helsinki schools. In addition to their use as practical guides to the local environment, these books played a role as emotional guidebooks. ${ }^{41}$ The books were still frequently used during the postwar era, and they were modified to fill the special needs of the postwar situation. The kotiseutuoppi education within an urban context was expected to teach local traditions and to educate children to adjust to new things. ${ }^{42}$ According to this mindset, teaching history had a place-not so much as a means of exploring a distant past, but, rather, as a means of introducing the kind of knowledge and competence required by contemporary demands. ${ }^{43}$

An important idea behind all kotiseutuoppi pedagogy was that children should leave the classroom to explore their local environment. On schoolorganized excursions, the teacher was supposed to lead the children to observe the environment in new and unconventional ways. Because the key idea motivating kotisentuoppi education was to use real-life topics, it was understood that in different settings, rural and urban, the excursions should also take a different shape. ${ }^{44}$ On excursions, the pupils were taught to make observations, to describe their visual encounters with the environment and to discover local signs of Finnishness. When returning to the classroom, the observations were to be captured on paper, often by drawing. Especially during the early years of education, fieldwork and local surveys formed an important part of the teaching, as they provided not only a means to teach features of the local environment but also fostered children's awareness of how society worked on a local level. ${ }^{45}$ The Käpylä

\footnotetext{
${ }^{40}$ Heikki Waris, "Suurkaupungin kotiseutuharrastus," in Kauppiaiden ja merenkulkijain Helsinki (Helsinki: Helsinki-Seura, 1954), 7-10.

${ }^{41}$ In the context of nineteenth-century Belgium, see Hoegaerts (2020), 66.

${ }^{42}$ Salo (1934), 29.

${ }^{43}$ Vahtikari (2017), 73-76.

${ }^{44}$ Lempi Vermasvuori, "Miten järjestän ympäristöopin retkeilyt," in Kansakoulun työtapoja. 1 osa, ed. by Kaarlo Saarialho, Matti Koskenniemi, Arvo Jääskinen, Aili Konttinen \& Vilho Myrsky (Helsinki: WSOY, 1948), 384-6, here 384.

${ }^{45}$ See also Teresa Ploszajska, "Down to earth? Geography fieldwork in English schools 1870-1944," Environment and Planning D: Society and Space, 16:6 (1998), 757-74, here 762 .
} 
collection of children's drawings reveals the different locations that students visited: the local church, nearby parks, construction sites and tram lines. The drawing assignments that teachers gave, such as "What did you do in the summer?" "The house where I live," "Our school," "The Church," "The view from my window," "Our day out in Helsinki," encouraged children to express their feelings, including love and appreciation for the home and the nation as subjective lived spatial experiences. Children also portrayed their everyday life in the school yard and at home.

Already in prewar kotisentuoppi education, supporting children's own initiative had been seen as important ${ }^{46}$; this objective became pronouncedly present in the postwar situation. The book issued by the Helsinki Society, designed to be used in elementary schools, also urged children to explore the city independently. The emphasis was on urban space as a learning environment, and the city itself was used as an "object lesson" linking the past to the present ${ }^{47}$ :

Outdoor trips are a really fun and useful way to learn. We like it a lot, said all three in unison. What has our wandering about in Helsinki been, other than studying outdoors. I doubt that we would ever have learned to know the city so well otherwise; just reading books would not have been sufficient. Books are useful to some degree, maps especially, but seeing and hearing first-hand is the most important thing. ${ }^{48}$

In the Helsinki Society book, siblings Anneli and Timo, after moving to Helsinki from the countryside, get to know their new place of residence bit-by-bit thanks to the help of their Helsinki-native cousin Kari. Their narrative evokes the idea of a gradual and circle-like widening of their realm of knowledge about their home environment: first by getting to know the home in a modern apartment building and the asphalt-covered yard, then by moving to the nearby blocks, and learning about the logic of urban traffic, and, finally, through exploring the city center and its key places of memory-churches, statues and major public buildings, and even the memorial graveyard for the fallen soldiers of World War II, the so-called Heroes' Cemetery. ${ }^{49}$ A similar kind of circle-like forming of knowledge of the urban

\footnotetext{
${ }^{46}$ Tuomaala (2005), 258.

${ }^{47}$ See also Håkan Forsell, "The City as Instructor. Pedagogical avant-garde and urban literacy in Germany around World War I," in Education, Childhood and Anarchism: Talking Colin Ward, ed. by Catherine Burke \& Ken Jones (London: Routledge, 2014), 3-18.

${ }^{48}$ Eero Salola, Helsinkiä oppimassa (Helsinki: Otava, 1957), 83.

${ }^{49}$ Salola (1957).
} 
environment can be found in the children's drawings. The home, the school building, the road to school, the local church, and the neighborhood are commonly used themes. There are also several images depicting gates as motifs-home gates, school gates, church gates-which can be interpreted as liminal spaces of stepping into or out of a wider sphere (Fig. 13.1). The drawings, just like the book by the Helsinki Society, were essentially about negotiating the boundaries of the growing metropolis. But they also embodied the idea that this circle of knowledge regarding the home would and should extend beyond city limits to the whole nation.

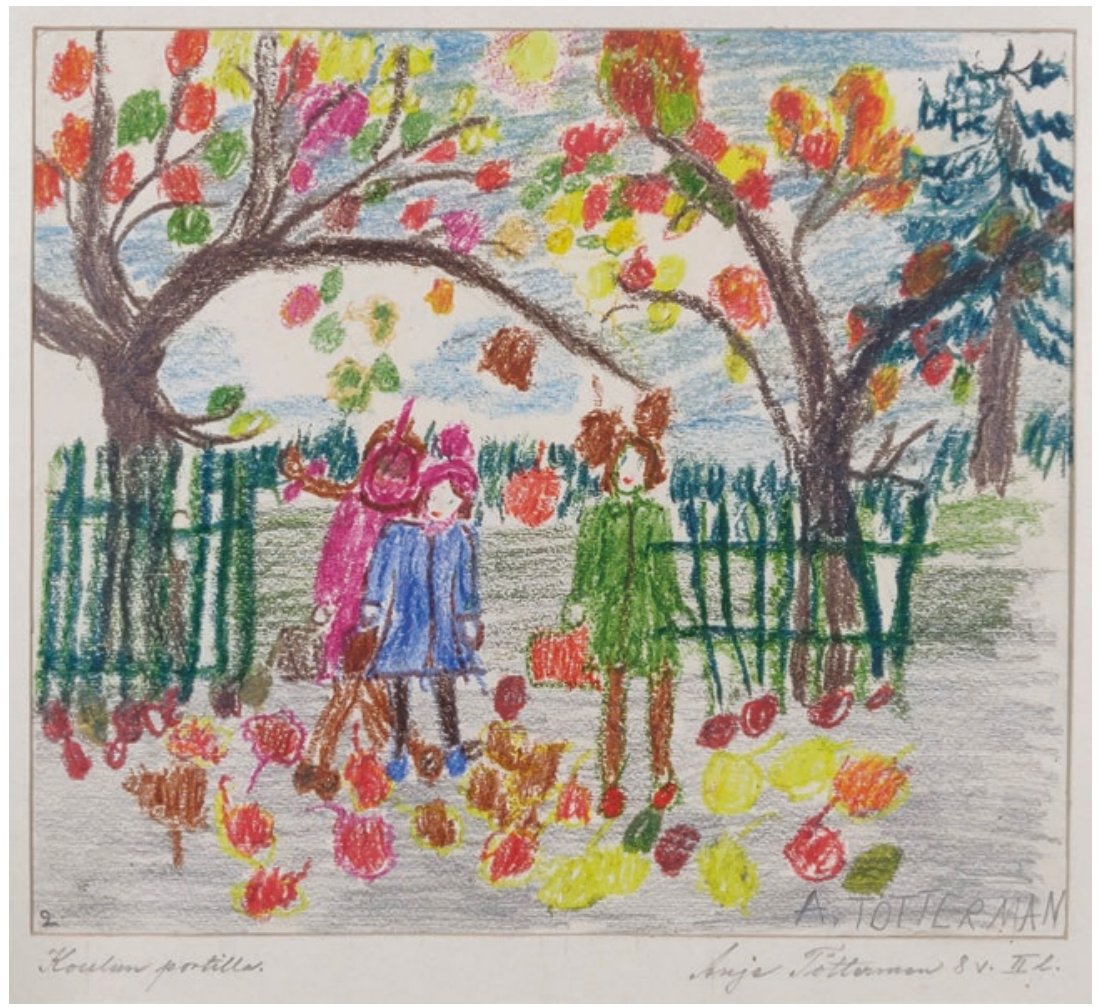

Fig. 13.1 "At the school gate" by eight-year-old Anje Tötterman, 1945-1950. Stepping from one sphere of experience into another. The image also testifies to the role of friendship in children's lives. (Photo: Aalto University's History of Art Education Archives, Helsinki) 
The visual materials used in teaching, such as educational images, reproductions of well-known landscape paintings, and schoolbook illustrations offered children ways of interpreting the relationship between the home environment and the nation. As the capital of the country, and representing power and national institutions, Helsinki had an obvious place within the Finnish national landscape imagery, while the overall emphasis was nevertheless on rural and natural environments. ${ }^{50}$ To some extent, Helsinki schoolchildren reproduced these visual themes in their drawings. At the same time, there exist almost no drawings using classical motifs of monumental Helsinki or the Finnish national landscape imagery in our material, such as panoramic views or images using a bird's-eye perspective. Children's drawings, instead, show a very multifaceted, locally bound Helsinki imagery. The drawing by an eight-year-old boy named Jouko, depicting a lively urban street view with stores and trams (Fig. 13.2), is a

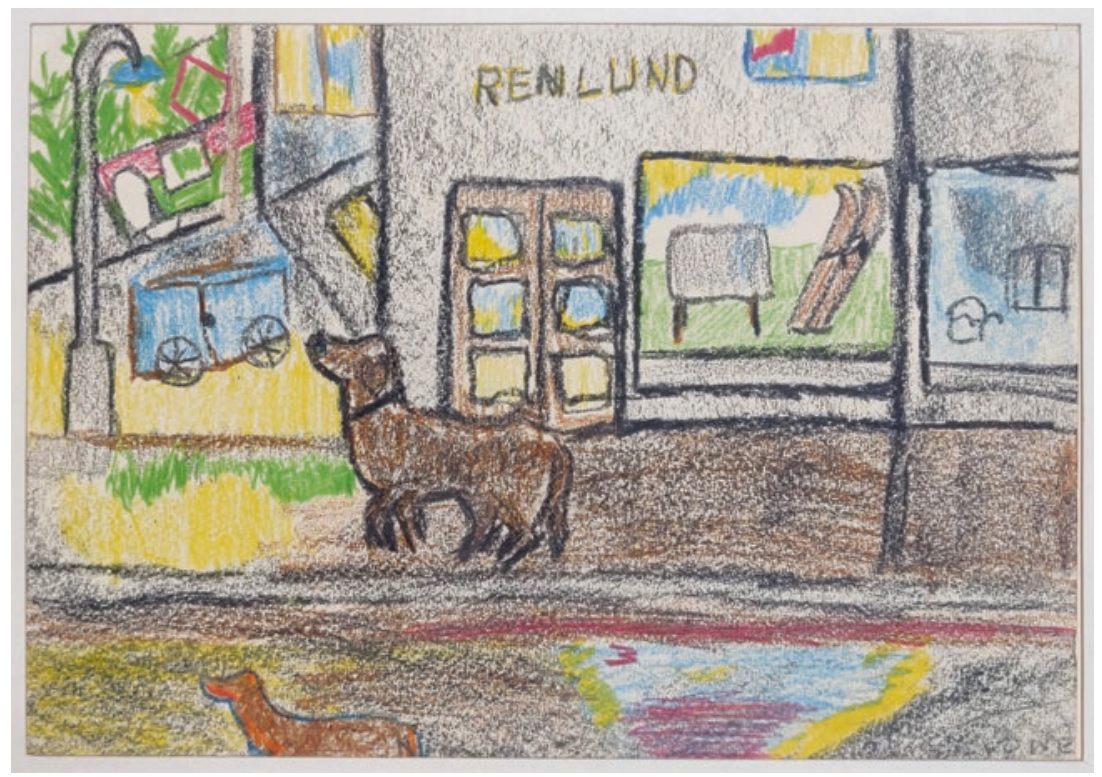

Fig. 13.2 Dogs rule the streets in the drawing by eight-year-old Jouko Iivonen, 1945-50. (Photo: Aalto University's History of Art Education Archives, Helsinki)

${ }^{50}$ Maunu Häyrynen, Kuvitettu maa: Suomen kansallisen maisemakuvaston rakentuminen (Helsinki: Finnish Literature Society, 2005), 72, 185. 
case in point. It also shows the multiple levels of meaning-making that can be present in a single drawing. The pair of skis he drew in a shop window are hardly there by accident. That would seem, rather, to be a statement of a child's desire in economically difficult times. Moreover, Jouko's drawing makes visible his freedom in handling the subject matter and the lack of any need to pursue realism in this small child's art: instead of human beings, the urban streets he draws are ruled by dogs. The children's drawings were thus hybrids created between established visual imageries and conventions, the teacher's instructions and the children's own worlds.

The books published by the Helsinki Society introduced children to urban vocabulary, and to practical competences needed for living in the city, whether related to safety in urban traffic or to thinking about and treating policemen "in a sympathetic and kind way." That teaching, as well as some of the drawing assignments given by teachers, drew from models of participatory, productive and responsible citizenship. ${ }^{51}$ The drawing by the eight-year-old girl Annikki depicts a mother and two children in an economically important and productive task, that of collecting scrap metal (see Fig. 13.3). The viewer's attention is drawn to the many sacks that the three are transporting, and especially to the mother's pulling and pushing of a heavy burden. This may be interpreted to reflect the major role that women and mothers played in the postwar society. Many other drawings and paintings in our material emphasize the role of the mother in a similar way-mothers appear more often than fathers in these images, and they are given prominent roles in them, be it holding hands or otherwise taking care of things. This indirectly suggests the absence of the father from the postwar family life for various, often war-related, reasons.

This and other drawings and paintings may also be associated with the reproduction of a wider reconstruction mentality and imagery in postwar Finnish society: they show industrious and active children who are working side-by-side with their parents. ${ }^{52}$ Here, the active part that the children are playing is underlined by their central positioning in the image. Even though it is highly likely that the assignment had been proposed by the teacher, Dagmar Kemilä, the autonomy and involvement of the child, both in the subject matter and the manner in which it is illustrated, again comes to the fore. The harmonious, "Finnish" winter landscape, with the rising or setting

${ }^{51}$ In the British context, see Kozlovsky (2015), 105.

${ }^{52}$ See also Anniina Koivurova, "Paljain jaloin. Rauhaan paluun arki koululaisten piirustuksissa ja maalauksissa," in Lappi palaa sodasta: Mielen hiljainen jälleenrakennus, ed. by Marja Tuominen \& Mervi Löfgren (Tampere: Vastapaino, 2018), 58-77. 


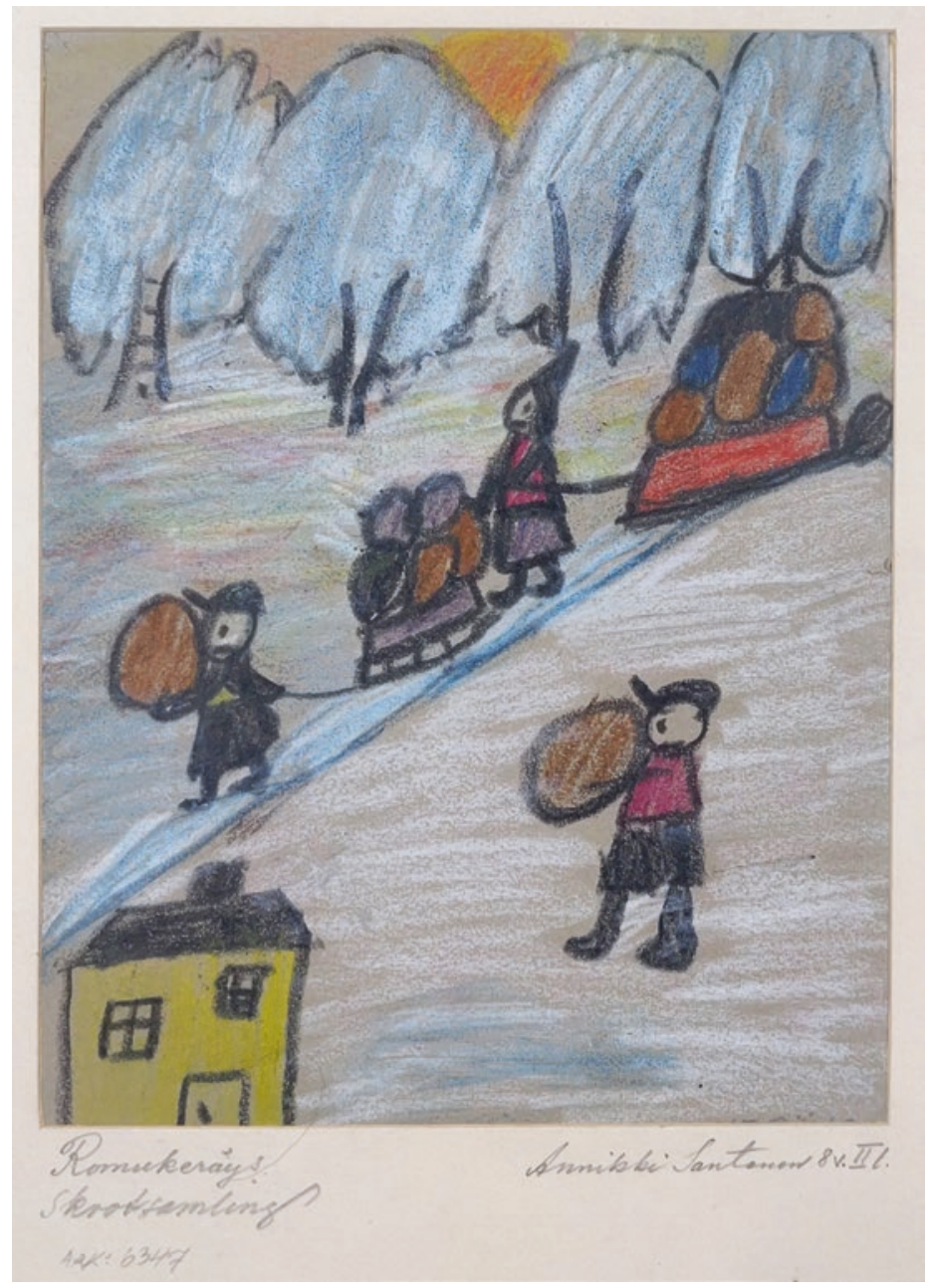

Fig. 13.3 "Collecting scrap metal" by eight-year-old Annikki Santanen, 1945-1950. Still, more than images of work, our collection of drawings and paintings contains many that show children playing. (Photo: Aalto University's History of Art Education Archives, Helsinki) 
sun, suggests that while the family had to work long hours for the nation the task itself was not unpleasant for the children and that it involved pride.

The urban self-adventure, supported by the educators, resembled, to a certain extent at least, the concept of adventure playgrounds promoted in postwar Britain. At an adventure playground, children were expected to design and construct the playground themselves, often from wartime rubble. In addition to the idea of appealing to children's own initiative and to models of participatory citizenship, freedom, within limits, was a feature of both..$^{53}$ In the Helsinki Society guidebooks, even though children were told to venture into the city on their own, the spontaneity of their urban exploration, in the experts' minds, was limited to the routes introduced and the destinations given. How children experienced the urban spaces introduced to them obviously varied, as the same spaces can trigger vastly divergent emotions in different people. The children thus experienced spaces in relation to their embodied history. According to historian Margrit Pernau, different groups within society had different experiences and emotions in similar spaces, "because their minds and bodies [had] learned to be affected differently." ${ }^{54}$ The spatial experience is also relational in another sense. The children felt and experienced spaces in relation to other spaces. For example, the freedom outside of home became even more meaningful for children living in overcrowded apartments.

The children's will and ability to explore the city reached well beyond the ideal routes proposed by experts, since, in the postwar period, they were allowed to move around very freely. They also expanded their territories bit-by-bit from their home yards to areas that were normally out of bounds to them. ${ }^{55}$ Käpylä and its surroundings, for example, had plenty of intriguing but dangerous places: rocks, forests, dumps, wastelands, railways, industrial areas and construction sites. Lacking day-care facilities and adult supervision, having short school hours, and learning in shifts, which meant that some children started their school day as late as $2 \mathrm{pm}$, all resulted in plenty of free time for the children.

Being able to freely move around meant there was an increasing risk of accidents, especially in traffic and at construction and railway sites. Not surprisingly, child experts and parents were worried that urban space

\footnotetext{
${ }^{53}$ Kozlovsky (2015), 102.

${ }^{54}$ Pernau (2014), 542.

${ }^{55}$ Simo Laakkonen, "Asphalt kids and the matrix city: reminiscences of children's urban environmental history," Urban History, 38:2 (2011), 301-23.
} 
would educate the children in an unproductive way. "Educators from the sideline" included environments out of bounds to children, but also, and perhaps more importantly, street life and its side effects. ${ }^{56}$ Clearly, there was a discrepancy between the visual imagery of kotiseutuoppi-related education, which led to the favoring of certain topics, and the children's everyday experiences and encounters with other dimensions of urban life and space in Helsinki. These encounters were, nevertheless, still related to the nation and its past, although even more to its violent history. For example, while walking in the streets, parks, and forests, children often encountered homeless veterans and war invalids (Fig. 13.4).

Historian Frank Biess has pointed out how postwar societies needed, at least partially, to redefine the parameters of acceptable and unacceptable emotions. ${ }^{57}$ For instance, in Finland state actors promoted a culture of resilience and self-restraint, and citizens, children included, were encouraged to put aside their personal past and present burdens. Often children had only limited capabilities of sharing and communicating their experiences of distress with adults: reactions to the children's plights could vary from empathy to anxiety and from suspicion to punitive reactions. ${ }^{58}$ At the same time, postwar societies offered places of emotional refuge from the established emotional norms. ${ }^{59}$ One such emotional refuge for children trying to have some freedom from their distressing home environment was offered by the self-exploration, especially the withdrawal to a natural (or an urban green) environment. For children living in difficult home conditions, the green space offered opportunities for social withdrawal where their privacy and freedom could be realized. These places are visibly present in the children's drawings.

Woods, meadows, rivers and other natural surroundings provided spaces in which children could process their feelings freely, without adult supervision or rules governing children's appropriate behavior. As a part of their

\footnotetext{
${ }^{56}$ Paavo Päivänsalo, "Kodin ja koulun ulkopuolella oleva ympäristö lapsen luonteen muovaajana," Lapsi ja Nuoriso 11:7 (1947), 163-4.

${ }^{57}$ Frank Biess, "Feelings in the Aftermath: Toward a History of Postwar Emotions," in Histories of the Aftermath: The Legacies of the Second World War in Europe, ed. by Frank Biess \& Robert Moeller (New York: Berghahn Books, 2010), 30-48.

${ }^{58}$ Antti Malinen \& Tuomo Tamminen, Jälleenrakentajien lapset: Sodanjälkeinen Suomi lapsen silmin (Helsinki: Gaudeamus, 2017); Kirsi-Maria Hytönen \& Antti Malinen, "Cos I'm a Survivor'. Narratives of Coping and Resilience in Recollections of Difficult Childhood in Post-war Finland," Ethnologia Fennica 45 (2018), 55-78.

${ }^{59}$ For emotional refuges, see William Reddy, The Navigation of Feeling: A Framework for the History of Emotions (Cambridge: Cambridge University Press, 2001).
} 


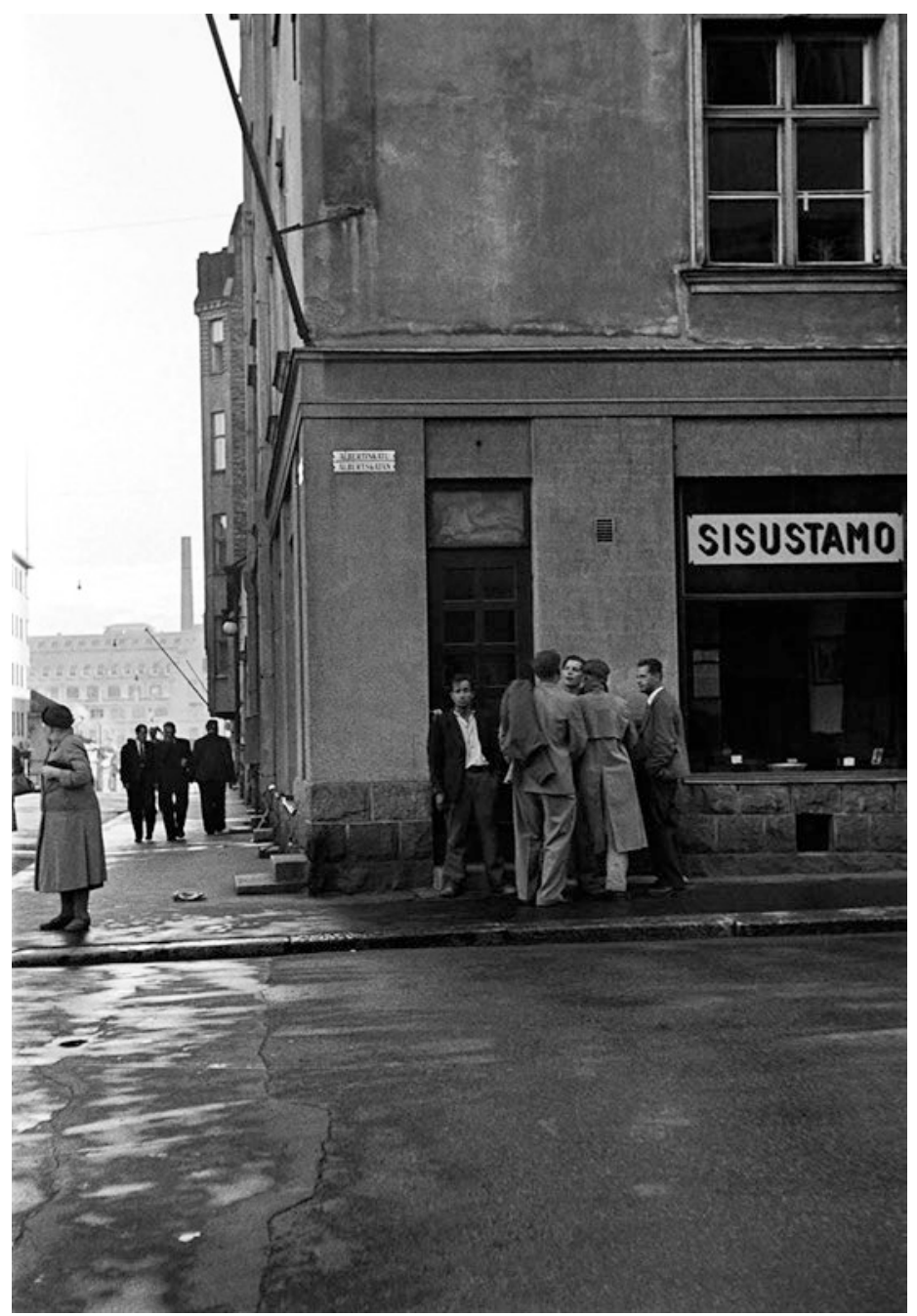

Fig. 13.4 Drunken men in Helsinki at the corner of Albertinkatu and Pursimiehenkatu streets. (Photograph taken in the 1950s. Photo: Helsinki City Museum) 
education, Finnish elementary school students were educated to move about in natural surroundings: they learned not only to value and make use of natural resources, such as wild berries and mushrooms, but also to use nature as a place of relaxation. From 1943 onward, pupils in Helsinki were also expected to contribute to the food supply, under the supervision of primary school teachers, by growing vegetables and picking forest berries and bringing them to the school kitchen. Some of the assignments given by Dagmar Kemilä, and the related drawings, one, for example, by eight-yearold Aila, entitled "Mushroom woodland," seem to reflect these demands and objectives related to postwar shortages (Fig. 13.5). The drawing depicts two children picking mushrooms by themselves and placing them in their baskets without adult supervision. The children are portrayed as making use of natural resources, of living their national obligations.

At the same time, there was still room for play and wonder, at least in Aila's representation. The child on the left seems to be observing an ant climbing up a spruce tree. The students were also taught to live their nation through appreciating the aesthetic and restorative qualities of nature. Study books used in primary schools depicted gardens and nature as comfortable and relaxing spaces, which encouraged a healthy and sober lifestyle and "cultivated the soul and heart for the benefit of human life and society." 60 As part of the above-mentioned assignment, Dagmar Kemilä arranged a field trip where she asked her pupils to observe the forest, as well as the intricate details of an individual tree, its foliage and needles.

The embodied practice of drawing offered another emotional refuge in the children's lives. We will discuss in the next section these "alternative spaces and places" ${ }^{\prime 1}$ of emotion that drawing created, and how they, often in very subtle ways, were linked to the nation.

\footnotetext{
${ }^{60}$ Kalle Kalervo, Koulupuntarba-aatteen kehitys meillä ja munalla (Helsinki: Kirja, 1913); Oiva Saari, Lyyli Miettinen \& Matti Koskenniemi, Luonto ja me: luonnontiedon oppikirja kaupunkien ja muiden asutuskeskusten kansakouluille (Porvoo: WSOY, 1952), 153.

${ }^{61}$ See also Anna-Kaisa Kuusisto-Arponen, "The Politics of Identity and Visuality: The Case of Finnish War Children," in Images in Use: Towards the Critical Analysis of Visual Communication, ed. by Matteo Stocchetti \& Karin Kukkonen (Amsterdam: John Benjamins Publishing Company, 2011), 181-98, here 186. For drawing as an emotional refuge for children, see also Koivurova (2018).
} 


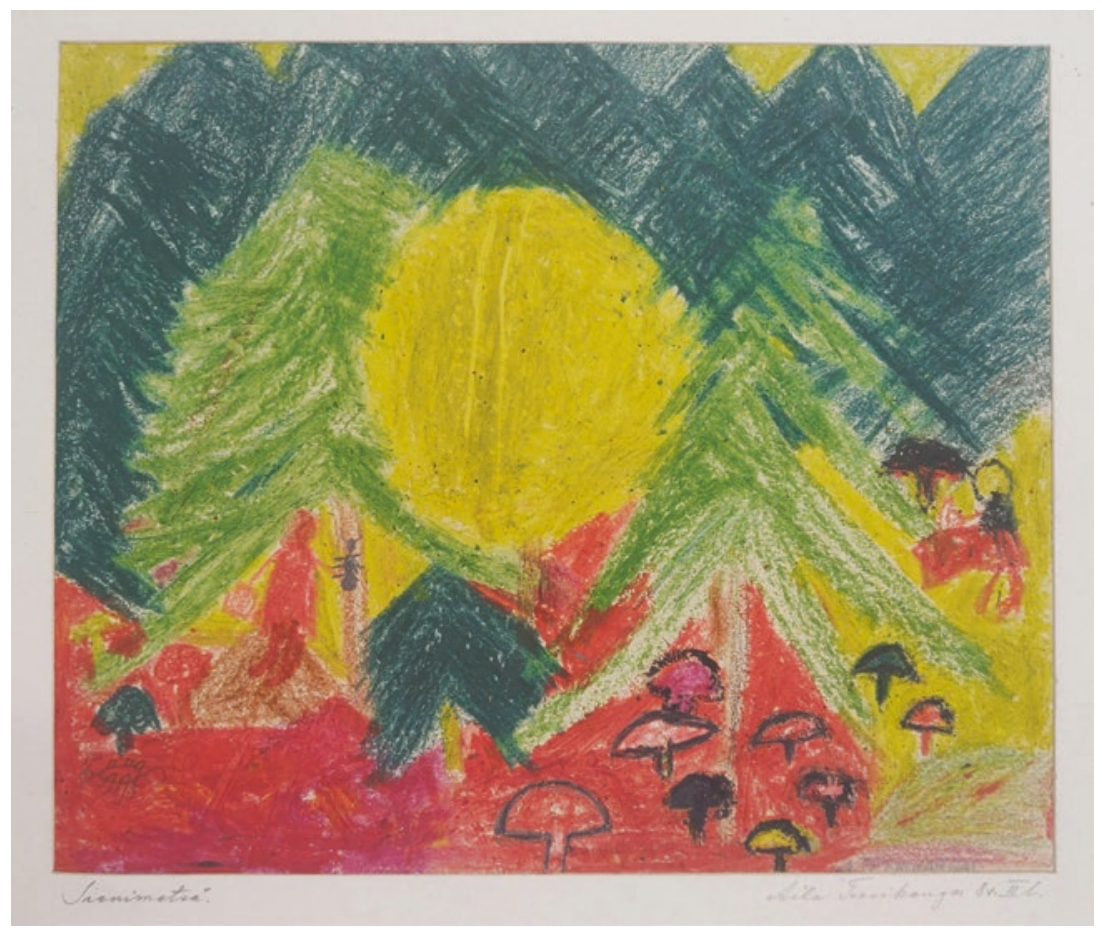

Fig. 13.5 "Mushroom woodland" by eight-year-old Aila Teerikangas, 1945-1950. (Photo: Aalto University's History of Art Education Archives, Helsinki)

\section{Learning National-Emotional Competences THROUGH ART}

At the turn of the nineteenth and twentieth centuries, pedagogues in Europe showed increasing interest in children's free and intuitive expression in drawing: as children saw the world differently compared to adults, it was felt that their drawings should not be measured according to adult criteria. ${ }^{62}$ Influences of the international art education movement are also clearly visible in two Finnish committee reports published in 1907

${ }^{62}$ Kay (2019), 189; Pignot (2019), 170-88; Mary Ann Stankiewicz, "Capitalizing Art Education: Mapping International Histories," in International Handbook of Research in Arts Education, ed. by Liora Bresler (Dordrecht: Springer, 2007), 7-38; Merja Mannila, "The early development of art education in Finland," in Images in time: essays on art education in 
and 1909. Both criticized the prevailing methods of art education, according to which students were asked to copy teachers' models in a mechanized way. The committees suggested instead that the emphasis should be more on stimulation and development of pupils' sense of beauty and perception. ${ }^{63}$ The need for revision of art education was also justified with respect to societal demands to educate healthy future citizens: "A trained eye is able to enjoy more than an untrained one, and a mind which is open to aesthetic values provides ways for a child to resist unhealthy influences." 64

According to architectural historian Roy Kozlovsky, the post-World War II generation in England redefined the politics of aesthetic education as "a technique for engineering a more peaceful society by transforming the emotional structure of the individual." ${ }^{65}$ Art historian Herbert Read, in particular, believed that by educating children in aesthetic techniques they could expand their capacity to communicate and express themselves. These were also activities that Read considered necessary for the development of balanced personalities with critical intellectual capacity. ${ }^{66}$

Educators in Nordic countries held similar beliefs, and reforms were often motivated by pointing to the experiences of the education programs of the totalitarian states. For example, the Finnish National Curriculum for 1952 stated explicitly that instead of forcing pupils to follow a single political ideology, they should be guided toward free and independent thinking, and intellectual curiosity. In the 1952 Curriculum, art education was considered to play a major role in the formation of future citizens, as it provided tools to foster children's creativity, imagination and abilities of self-expression-all features that gained new significance in post-World War II societies. ${ }^{67}$ In Finnish art education, and in educational thinking overall, the reformist ideas were in the air, but undoubtedly many teachers still continued to teach using old methods in their day-to-day work.

Finland, ed. by Maria Laukka et al. (Helsinki: Helsinki University of Industrial Arts, 1992), 31-7.

${ }^{63}$ Piirustuskomiteamietintö [Committee for the Art Education Report] 1907: 13a, p. 15;

Piirustuskomiteamietintö 1909: 8a.

${ }^{64}$ Piirustuskomiteamietintö 1909: 8a, 8-9.

${ }^{65}$ Kozlovsky (2016), 125.

${ }^{66}$ Kozlovsky (2016), 125.

${ }^{67}$ Committee for the Elementary School Curriculum Report 1952:3, 13, 19, 28. 
Dagmar Kemilä became one of the most well-known representatives of the new style of art education in Finland. From the 1920s until the 1950s, Kemilä made several study trips to Central Europe. She also took an active part in educating elementary school teachers around the country. She gave lectures, wrote articles related to the teaching of kotiseutuoppi and art education, and lectured regularly on the national School Radio. ${ }^{68}$ In 1947, the National Board of Education, together with Kemilä, organized an exhibition at the design company Artek's showroom in Helsinki, aiming to introduce Kemilä's successful teaching methods to a wider audience in Finland. Both art critics and the public praised Kemilä's students' works, which were put on display for their "joyful play of color." ${ }^{69}$ The Ministry of Education was so impressed that it decided to send the drawings to an international exhibition organized by the Union des Arts Plastiques at the Louvre in Paris. ${ }^{70}$ Kemilä's students won several prizes at the Louvre exhibition, and their drawings were also later displayed in New York and Japan. ${ }^{71}$ While the young artists had not done their drawings for any particular audience, Dagmar Kemilä probably gave the assignments with audiences sometimes in mind. In the international context, the children's drawings represented not just Kemilä's teaching methods but also Finland and the Finnish way of life.

Kemilä saw art education as a way of facilitating the development of the children's imagination and emotional life. In one of her articles, she described in detail her method of awakening students' inner vision:

When the subject is explained and demonstrated in words and with gestures, the students gather their thoughts, concentrate, calm down at their desks, close their eyes for moment and start to grow their inner visions. These minutes of inner awakening are the most positive and adorable moments of the class. It's like life itself lays its invisible hand on them. One can only hear their steady breathing, and now that the teacher's part of the task has been transferred to the pupils, he/she can stand back and wait for the pupils to bring their vision to life. ${ }^{72}$

${ }^{68}$ Helsingin Sanomat 4 June 1936; Opettajain Lehti 33:51 (1938), 1483; Dagmar Kemilä, "Huomiointia alakansakoulun piirustuksen opetuksesta," Stylus 26 (1941), 45-52.

${ }^{69}$ Suomen Kuvalebti 19 April 1947 II, 3.

${ }^{70}$ Uusi Suomi 21 March 1947.

${ }^{71}$ Uusi Suomi 1 March 1947.

${ }^{72}$ Kemilä (1941). 
After the awakening of their inner vision, the children could start to draw. We argue that during art classes the children became engaged in multilayered narrative worlds: while drawing and painting they transformed field-trip experiences into new visual narratives, and again reinterpreted them when explaining - to the teacher and to other students-what was happening in their drawings. Kemilä understood visualization through drawing and the relating of the children's stories as two interwoven processes. ${ }^{73}$ It can be argued that in these narrative worlds, the children were able to experience a "simulated reality" and feel in response to the stories and images they heard, saw or created themselves. As historians Pascal Eitler, Stephanie Olsen and Uffa Jensen point out, "reading can be an active experience through which readers can explore their imagination, participate in the production of the text's meaning, and exercise varying degrees of autonomy." ${ }^{74}$ We propose to expand this notion to drawing.

This kind of engagement with narrative fiction and mental simulation of social experiences may improve social skills, such as the ability to feel empathy. ${ }^{75}$ Education concerning empathy became in itself one of the objects of the postwar curriculum, as school authorities acknowledged that many students, such as war orphans and evacuees, had experienced war-related losses, and were in need of support. ${ }^{76}$ The National Board of Education emphasized in its circulars that teachers should do all that they could to help, for example, evacuated children to feel comfortable and welcome in their new environments. According to this view, stories in school books or in children's books could impart and share "situated and practical knowledge, telling children not necessarily what to feel but how this or that emotion occurs, what it looks like and the physical experience of it, in some level of detail." 77 Also, art teaching was used to similar effect. Dagmar Kemilä gave students motifs such as "My church" and "Easter" when teaching religion, but at the same time they were introduced to

\footnotetext{
${ }^{73}$ Kemilä (1941).

${ }^{74}$ Pascal Eitler, Stephanie Olsen \& Uffa Jensen, "Introduction," in Learning How to Feel. Children's Literature and Emotional Socialization, 1870-1970, ed. by Ute Frevert et al. (Oxford: Oxford University Press, 2014), 1-20.

${ }^{75}$ Raymond A. Mar, Keith Oatley \& Jordan B. Peterson, "Exploring the link between reading fiction and empathy: Ruling out individual differences and examining outcomes," Communications 34:4 (2009), 407-28.

${ }^{76}$ See Kouluhallituksen kansaopetusosaston II arkisto, Dc:4, kiertokirjeet 1944-45, Circular 7 September 1944.

${ }^{77}$ Eitler, Olsen \& Jensen (2014).
} 
emotions such as grief and feelings of loss as they drew church services, funerals, grieving relatives, or other religious themes related to Easter and the suffering of Jesus. ${ }^{78}$

Our analysis points to the fact that teachers played a major role in the formation of emotional skills such as empathy. Dagmar Kemilä's pedagogy was well-suited to the new postwar situation. For example, she believed that classrooms could become sites where children learned to express their feelings courageously, without fear, and that this learning started by imitating teachers. ${ }^{79}$ The teacher's duty was to invite students into a mimetic learning experience, by behaving and speaking in a warm manner that facilitated open discussion, and even by wearing colorful and nice clothes that made them more approachable to children. Kemilä also believed that teachers should present examples of drawing techniques that encouraged students to use their imagination and to express emotions. Kemilä herself taught the children to hold several crayons in their hand simultaneously, and even to draw with both hands at once, in order to develop speed and spontaneity. The drawing paper was also as large as practically possible in order to provide room for the children's expression. ${ }^{80}$ Kemilä also expected students to be able to explain in detail what they had drawn, in order to develop their ability to communicate and express their feelings and ideas. Just as with the school excursions, the practice of drawing engaged a wide spectrum of the children's senses. Borrowing from Josephine Hoegaerts, who has examined school excursions in nineteenth-century Belgium, we argue that these multisensory experiences allowed pupils a concrete, physical and very direct interaction with the nation, and "a heightened awareness of that close interaction." 81 The nation was learned and felt in situated activities.

One of the prize-winning works in Paris was a drawing by the eightyear-old schoolgirl Leena, entitled "The Lovely Sun" (Fig. 13.6). This was a theme that Kemilä seems to have been particularly interested in. She used it as an example in her writings on several occasions. ${ }^{82}$ With its bright

\footnotetext{
${ }^{78}$ Dagmar Kemilä, "Minun kirkkoni," Schoolradio 1942, 22-3, 36. See drawings 6294, boy, eight years old, 1945-1950; 6296, boy (no information on age), 1945-1950; 6297, girl, eight years old, 1946.

${ }^{79}$ Uusi Suomi I May 1947.

${ }^{80}$ Suomen Kuvalehti 19 April 1947 II, 3.

${ }^{81}$ Hoegaerts (2020), 73-4.

${ }^{82}$ Dagmar Kemilä, “Aurinko armas [Dear Sun],” Kouluradio (1942), 44.
} 


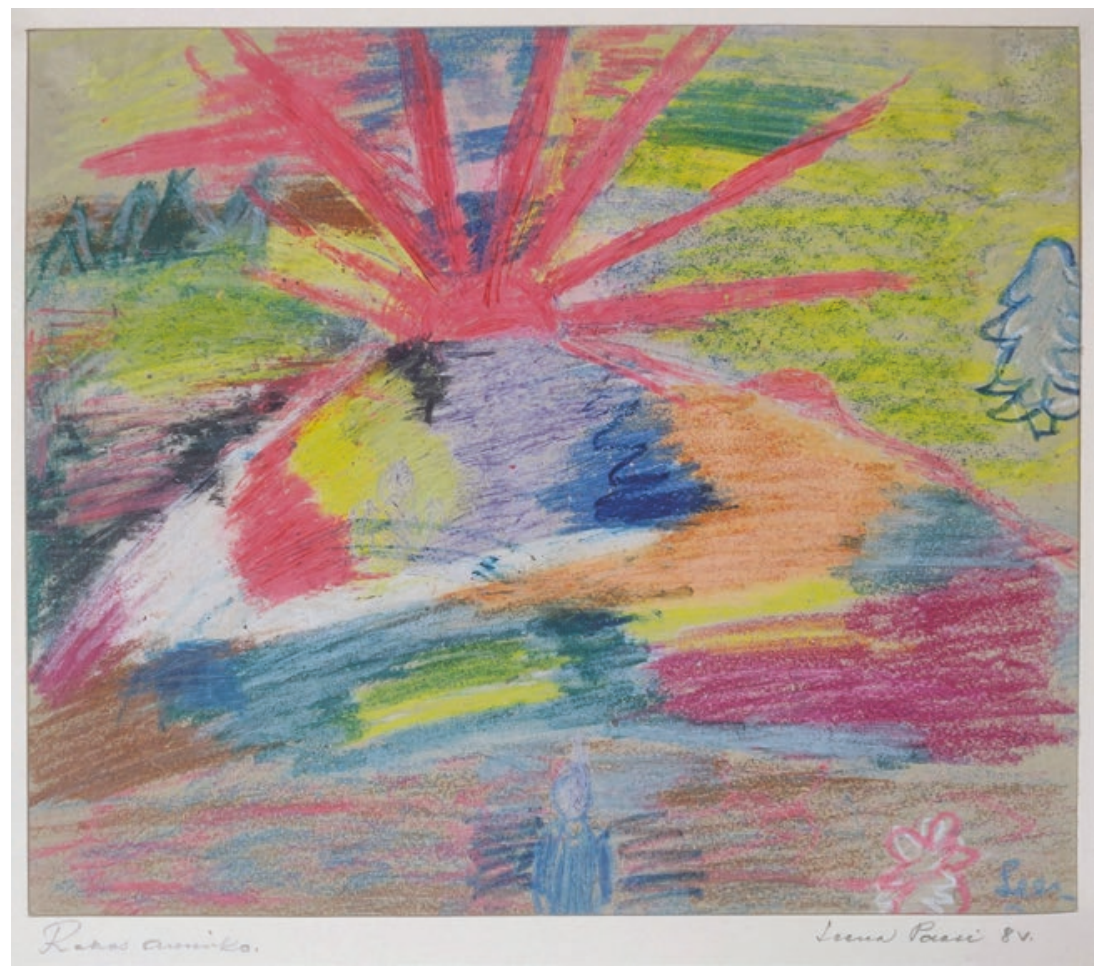

Fig. 13.6 "The Lovely Sun" by 8-year-old Leena Paasi, 1945-1950. (Photo: Aalto University's History of Art Education Archives, Helsinki)

colors, an expressive technique and a feeling of spontaneity, Leena's work is illustrative of drawing as an engagement with multilayered narrative worlds and the kind of national-emotional work we have described above. As already mentioned, one of the major objects in Kemilä's teaching was to foster children's ability to feel empathy toward other human beings, animals and nature as a whole. In Leena's drawing, a young child seems to be facing the sun, and connecting with it, by feeling the warmth and brightness of its rays. This experience of connection, and of being able to feel connected, to home, locality, nation and to the wider world was something that teachers hoped to foster in children, as a way of socializing them to become competent and adaptive future citizens. ${ }^{83}$

${ }^{83}$ Committee for the Elementary School Curriculum Report 1952: 3, 24. 
Written on the back of the drawing one can find Kemilä's remarks on her approach to the motif "lovely sun," and how she instructed her students:

When observing the sun in nature, we realize its brightness. We will not draw a face for the sun. If we did so, we would no longer be considering the sun to be great, wonderful and lovely. Only from storybooks will children learn to draw a face for the sun. The sunbeams we shall draw as straight lines, which are not like the withered petals of a day flower.

These instructions show how Kemilä guided her young students, and how she expressed her own ideals with regard to a desirable outcome. The children were not given total freedom to express their inner vision. In the process, the teacher's and the children's emotions became entangled.

\section{Conclusions}

The nation in the postwar period was reproduced for and by children in multifaceted ways. This was done not simply by educators offering ideological concepts and ideas, and/or through the representations of the nation, but equally in material and spatial everyday encounters, and in everyday school practices, such as exploring the urban environment, withdrawing to green space and drawing. At play were a whole range of "explicit and non-intentional-but still educative-encounters," such as emotions, stimulation of the will to learn in children, and nonhuman teachers (such as the space and environment). ${ }^{84}$ The nation for postwar children was a lived experience: not as openly nationalist as had been the case in the interwar period, but nevertheless present. In the postwar period, this experience was becoming increasingly urban.

The case study of postwar Helsinki illustrates the importance of fully acknowledging the spatiality and materiality of emotions when discussing children's emotional formation and historical manifestations of everyday nationalism. In the field of the history of childhood, children's own experiences, in respect to what adults thought children should be experiencing, are a key area of interest. As Stephanie Olsen points out, "it is in the dynamic relation between stakeholders of

${ }^{84}$ Millei (2019), 85. 
childhood (including, most importantly, children) and childhood itself that the new narrative of children's emotions emerges." 85 Educators hoped to encourage certain ways of experiencing the city in relation to the national space and frames of experiencing. Postwar National Curriculums in Finland (1946 and 1952) emphasized the role of art education, as it offered a means to teach children emotional competences and to foster their development into balanced and peace-loving personalities. In our analysis, we took a closer look at Dagmar Kemilä and her exceptionally progressive art-teaching techniques. Kemilä believed that aesthetic techniques such as drawing and connected excursions and discussions would expand children's capacities for emotional expression and communication. In the process, new forms of national belonging, suited to the postwar society, were negotiated in embodied and sensory ways.

The children's spatial encounters and drawings were influenced by the objectives of the kotisentuoppi education; the assignments given by the teacher; the teacher's personality and her own feelings and ways of being in the world; the broad visual culture surrounding the children, and the social and material realities of the city. Still, as historian Manon Pignot asserts, children "were not mere copyists, we must also imagine these drawings as alternative forms of personal expression." ${ }^{86}$ By exploring and drawing, postwar children living in Helsinki gave meaning to the urban environment as part of the wider national space.

\footnotetext{
${ }^{85}$ Stephanie Olsen, "Introduction," in Childhood, Youth and Emotions in Modern History: National, Colonial and Global Perspectives, ed. by Stephanie Olsen (Basingstoke, Hampshire: Palgrave Macmillan 2015), 2.

${ }^{86}$ Pignot (2017), 312.
} 
Open Access This chapter is licensed under the terms of the Creative Commons Attribution 4.0 International License (http://creativecommons.org/licenses/ by $/ 4.0 /$ ), which permits use, sharing, adaptation, distribution and reproduction in any medium or format, as long as you give appropriate credit to the original author(s) and the source, provide a link to the Creative Commons licence and indicate if changes were made.

The images or other third party material in this chapter are included in the chapter's Creative Commons licence, unless indicated otherwise in a credit line to the material. If material is not included in the chapter's Creative Commons licence and your intended use is not permitted by statutory regulation or exceeds the permitted use, you will need to obtain permission directly from the copyright holder.

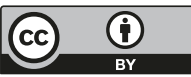

